\title{
The Frequency of C677T Methylenetetrahydrofolate Reductase (MTHFR) Polymorphism in Southern East Bosnian Population
}

\author{
Karić Amela ${ }^{1 *}$, Terzić Rifet ${ }^{1}$, Jerkić Zoran² and Mustedanagić-Mujanović Jasminka ${ }^{3}$
}

${ }^{1}$ Division of Genetics, Faculty of Science, University of Tuzla, Univerzitetska 4, 7500 Tuzla, Bosnia and Herzegovina

${ }^{2}$ Clinics for Cardiovascular Diseases, University Clinical centre Tuzla, Trnovac bb, 7500 Tuzla, Bosnia and Herzegovina

${ }^{3}$ Polyclinics for Laboratory Diagnostics, University Clinical centre Tuzla, Trnovac bb, 7500 Tuzla, Bosnia and Herzegovina

\begin{abstract}
The C677T MTHFR polymorphism is distributed widely among ethnics populations and showing a high heterogeneity. The fact that there were no published data on the prevalence of C677T MTHFR polymorphism in Bosnia and Herzegovina prompted us to determine its prevalence in sample of Bosnian population.

Two hundred and seven unrelated, apparently healthy subjects from Southern east Bosnia were included in study. Genotyping of C677T MTHFR polymorphism was done using polymerase chain reaction (PCR) followed by restriction digestion (RFLP) with Hinfl enzyme.

Out of 207 healthy subjects, $44.44 \%$ were heterozygous and $11.11 \%$ were homozygous for C677T MTHFR polymorphism. Allele and genotype frequency of MTHFR C677T did not differ between males and females carriers $\left(X^{2}=0.87 ; \mathrm{df}=1 ; \mathrm{P}=0.350\right)$. This study is the first to report frequency of $\mathrm{C} 677 \mathrm{~T}$ polymorphism in healthy Bosnian population. Frequency of the T allele and C677T MTHFR genotype observed in this study is consistent with the data from literature.
\end{abstract}

Keywords: C677T Methylenetetrahydrofolate Reductase (MTHFR) polymorphism; PCR; RFLP

\section{Introduction}

Methylenetetrahydrofolate Reductase (MTHFR) enzyme catalyzes the reduction of 5, 10-methylenetetrahydrofolate to 5 -methylenetetrahydrofolate, and the methyl donor for the conversion of homocysteine to methionine [1].

The 5, 10-methylenetetrahydrofolate reductase (MTHFR) gene is located on chromosome 1 at $1 \mathrm{p} 36.3$. The complementary DNA sequence is 2.2 kilo bases long and consists of 11 exons [2]. Genetics polymorphism in the MTHFR gene are well established, the most extensively studied of which is C677T single-nucleotide polymorphism (SNP) [3]. The C677T SNP results in a missense mutation that converts a cytosine $(\mathrm{C})$ into thymine $(\mathrm{T})$ which is leading to substitution of valine for alanine at position 222 of the MTHFR enzyme, causing the synthesis of a thermo labile enzyme with a $50 \%$ reduction activity [4-6].

Reduced MTHFR enzyme activity is subsequently followed by increases in circulating homocysteine levels hyperhomocysteinemia) [7]. Hyperhomocysteinemia now is recognized as an independent risk factor for vascular diseases [8] and defects of the neural tube [9].

The T677 allele is distributed widely among populations showing a high heterogeneity [10]. Its frequency varies in different geographical regions and ethical groups. A number of studies have reported the frequencies of C677T in European and American Caucasian populations.

The fact that there were no published data on the prevalence of C677T MTHFR polymorphism in Bosnia and Herzegovina prompted us to determine its prevalence in healthy subjects in Sotherneast Bosnian population.

\section{Materials and Methods}

\section{Subjects}

We studied a total of 207 (102 man and 105 women) unrelated, apparently healthy subjects from Southern east Bosnia. Their mean age was 45.62 years (range 18-84) at time of blood sampling.

All subjects were fully informed about study protocol and have consented to participate in the study by signing the written consent. The study was approved by the Ethics Committee on Human Research of University Clinical Center Tuzla.

\section{Methods}

The DNA was isolated from EDTA anticoagulated whole blood (Vacuatainer Becton Dickinson, Meylan Cedex, France) using the commercial Flexi Gene (250) Isolation Kit (QIAGEN, GmbH, Hilden, Germany). The C677T MTHFR polymorphism was genotyped by polymerase chain reaction followed by restriction digestion (PCRRFLP). A $25 \mu \mathrm{L}$ PCR reaction was performed by using $1 \mu \mathrm{L}$ genomic DNA, $10 \times$ PCR Buffer, dNTP (2,5mM), $\mathrm{MgCl}_{2}$ (1, $\left.5 \mathrm{mM}\right), 5^{\prime}$-TGA AGG AGA ACG TGT CTG CGG GA-3' forward primer and 5'-AGG ACG GTG CGG TGA GAG TG-3' reverse primer (Eurofins MWG Operon,

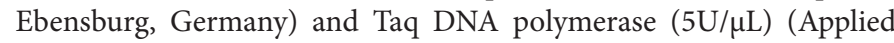
Biosystems by Roche Molecular systems Inc, New Jersey, The USA).

The PCR amplification cycles were modified as follows: 5 min initial at $95^{\circ} \mathrm{C}$, followed by $30 \mathrm{cycles}$ of $30 \mathrm{sec}$ of denaturation at $95^{\circ} \mathrm{C}, 30 \mathrm{sec}$ of annealing at $60^{\circ} \mathrm{C}$ and $60 \mathrm{sec}$ of extension at $72^{\circ} \mathrm{C}$ in an Applied Biosistems Thermal Cycler (Applied Biosystems by Roche Molecular systems Inc, New Jersey, The USA) apparatus.

The Ala223val substitution, due to the C677T transition in the

*Corresponding author: Karić Amela, Division of Genetics, Faculty of Science, University of Tuzla, Univerzitetska 4, 7500 Tuzla, Bosnia and Herzegovina, Tel: +387 61289 217; Fax: +387 35320 861; E-mail: amela.jusic@untz.ba

Received July 18, 2013; Accepted August 08, 2013; Published August 14, 2013

Citation: Amela K, Rifet T, Zoran J, Jasminka MM (2013) The Frequency of C677T Methylenetetrahydrofolate Reductase (MTHFR) Polymorphism in Southern East Bosnian Population. J Biomet Biostat 4: 169. doi:10.4172/2155-6180.1000169

Copyright: (C) 2013 Amela K, et al. This is an open-access article distributed under the terms of the Creative Commons Attribution License, which permits unrestricted use, distribution, and reproduction in any medium, provided the original author and source are credited. 
MTHFR gene, creates an additional HinfI restriction site in the PCR amplified fragment as described Frost et al. [6] which is detected by digestion of the $198 \mathrm{bp}$ PCR product, generating $23 \mathrm{bp}$ and $175 \mathrm{bp}$ fragments in homozygous (genotype TT). Genotype CC is characterized by the presence of a $198 \mathrm{bp}$ fragment, and genotype CT characterized by the presence of two fragments, on with $198 \mathrm{bp}$ and other with $175 \mathrm{bp}$. Restriction fragments were subjected to $4 \%$ agarose gel electrophoresis (Figure 1)

\section{Statistical analysis}

Statistical analyses was accomplished by using MedCalc 9.6.2.0 statistical software package The frequencies of $\mathrm{T}$ and $\mathrm{C}$ alleles and genotypes among gender in Southern east Bosnian population were compared by a chi-squared test. The difference in the prevalence variant C677T mutation is statistically significant if $\mathrm{P}<0.05$.

\section{Results}

Two hundred and seven healthy blood donors (102 males and 105 females) representing the Southern east Bosnian population were tested for C677T MTHFR polymorphism. The frequencies of genotypes distribution in study group are presented in Table 1. Of the 207 subjects $41.15 \%$ (males) and $46.66 \%$ (females) had wild type genotype. Among carriers of C677T MTHFR polymorphism 48.03\% (males) and $40.95 \%$ (females) were found to be heterozygous. Of 102 male subjects $10.78 \%$ were homozygous for C677T MTHFR polymorphism. Similar frequencies for homozygous genotype of C677T MTHFR polymorphism were observed in female's subjects (11.42\%). We did not find statistically significant differences in the percentage distributions of C677T MTHFR polymorphism between males and females carriers in Southern east Bosnian population $\left(X^{2}=0.87 ; \mathrm{df}=1 ; \mathrm{P}=0.350\right)$. The distribution of $\mathrm{C}$ and $\mathrm{T}$ alleles among males and females carriers of C677T MTHFR polymorphism are shown in Table 2. The frequency of normal C allele was $0.68 \%$ in male's subjects and $0.71 \%$ in female's subjects. The frequency of $\mathrm{T}$ allele in both subjects was similar $(0.32 \%$

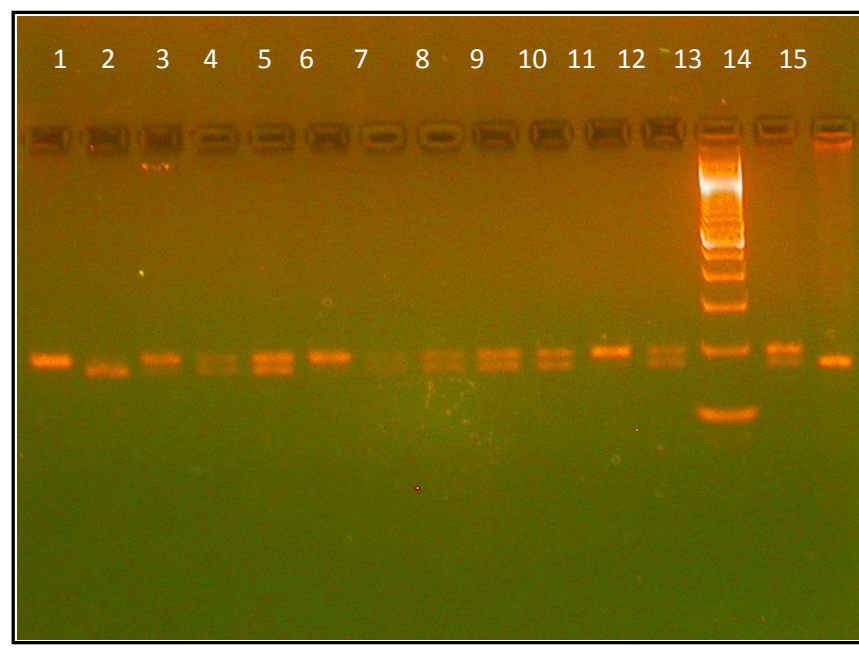

Figure 1: Detection of genotypes of the C677T MTHFR polymorphism by Hinfl restriction analysis.

Lines 1, 6 and 11 represents three subjects with normal genotype (198 bp fragment only), whereas lines $3,4,5,7,8,9,20,12$ and 13 show digested fragments (198 and $175 \mathrm{bp}$ ) from nine subjects. Lines 2 and 15 represents two homozygous carriers. The molecular weight marker used is $100 \mathrm{bp}$ ladde (Newe England Biolab, The UK) in line 13.

On the figure 1 are presented genotype for C677T MTHFR polymorphism after subjecting to $4 \%$ agarose gel electrophoresis.

\begin{tabular}{|l|c|c|c|}
\hline & Wild genotype CC & Heterozygous CT & Homozygous TT \\
\hline Males & $42(41.17)$ & $49(48.03)$ & $11(10.78)$ \\
\hline Females & $49(46.66)$ & $43(40.95)$ & $12(11.42)$ \\
\hline Total & $\mathbf{9 1 ( 4 3 . 9 6 )}$ & $\mathbf{9 2}(\mathbf{4 4 . 4 4 )}$ & $\mathbf{2 3} \mathbf{( 1 1 . 1 1 )}$ \\
\hline
\end{tabular}

Table 1: The frequencies of genotypes of C677T MTHFR polymorphism in study group.

\begin{tabular}{|l|c|c|c|c|}
\hline & \multicolumn{2}{|c|}{ Males } & \multicolumn{2}{c|}{ Females } \\
\hline & N & $\%$ & N & $\%$ \\
\hline Allele C & 133 & 0.68 & 141 & 0.71 \\
\hline Allele T & 60 & 0.32 & 55 & 0.29 \\
\hline
\end{tabular}

Table 2: The frequencies of $C$ and $T$ alleles among males and females carriers of C677T MTHFR polymorphism.

males and $0.29 \%$ females). The differences in distribution of $\mathrm{C}$ and $\mathrm{T}$ alleles among males and females in study group was not observed $\left(X^{2}=0.428 ; \mathrm{df}=1 ; \mathrm{P}=0.512\right)$.

\section{Discussion}

Although over the last few years C677T MTHFR polymorphism has been widely investigated, the results of this study are the first data on the frequency of C677T polymorphism in healthy representing Southern east Bosnian population. Population genetics studies are one way to highlight geographical and ethnic differences that suggest evolutionary pressures generated by environmental factors. Such possible pressures on the nutritional environment remain speculative in the case of MTHFR polymorphisms [11]. The frequency of T allele in different populations ranges from 0.06 to 0.59 and the frequency if the TT genotype ranges from 0.00 to $35 \%$.

According to the literature the Mexican population has the highest $\mathrm{T}$ allele frequency of 0.59 and TT genotype frequency of 35\% [12].The same study reports the lowest $\mathrm{T}$ allele frequency in sub-Saharan African and Canadian Inuit populations. Also, there are differences among the European populations. The frequency of heterozygous carriers is the largest in Italy (44\%), as opposed to Norway, where it is lower (28\%). Meta analysis of studies among European populations has shown that the frequency of homozygous carriers ranges from 5-15\% [10,13]. Rosenberg et al showed that the MTHFR 677T variant has occurred on a common haplotype in Israelis, Japanese, and Ghanaians [14].

In our study the statistical analysis showed no significant difference in the prevalence of C677T MTHFR polymorphism between males and females carriers. The frequency of $44.44 \%$ heterozygous and $11.11 \%$ homozygous of C677T MTHFR polymorphism cases among representing Southern east Bosnian population is consistent with the data from literature. Most of the studies reviewed did not specify the gender composition of the samples, did not comment on differences in genotype frequencies by sex, or reported that genotype frequency was not significantly different in males and females [15].

Beside of high frequency of C677T polymorphism at global level we can speculate that it is evolutionary very old. The reason for high frequency of the $\mathrm{T}$ allele in many populations is unclear. Fodinger et al. postulated hypotheses that in time of great death, reduced activity of MTHFR which leads to decreased metilation of homocysteine and allowed $\mathrm{C} 1$ units of tehtrahydrofolate metabolism to be accessible for nucleotide synthesis [16]. On the other hand the benefit deriving from a high dietary intake of folate by $677 \mathrm{~T}$ allele carriers may be due to various mechanisms, such as the increased synthesis of purines and pyrimidines needed for DNA replication [17]. In addition, folate may neutralize the adverse cellular effects of the reduced activity of the 
Citation: Amela K, Rifet T, Zoran J, Jasminka MM (2013) The Frequency of C677T Methylenetetrahydrofolate Reductase (MTHFR) Polymorphism in Southern East Bosnian Population. J Biomet Biostat 4: 169. doi:10.4172/2155-6180.1000169

thermolabile MTHFR variant, such as the defective remethylation of homocysteine, the subsequent DNA hypomethylation, and the uracile misincorporation and it may also influence epigenetic mechanisms regulating gene expression [11].

The C677T transition in the MTHFR gene results in elevated levels of plasma homocysteine in homozygous carriers, especially in the presence of low folate levels [15]. The variant enzyme has reduced activity and inherited as an autosomal recessive trait. In many populations the inherited thermolabile variant for MTHFR is associated with higher serum homocysteine levels. This polymorphism has been regarded as a genetic risk factor for various disorders, such as coronary artery diseases, neural tube defects, cleft lip, venous thromboembolism, recurrent spontaneous abortions, primary angle glaucoma [18-24]. Also, the relationship between the MTHFR C677T polymorphism and its exact action with type 2 diabetes lellitus (T2DM) worldwide is under question. Several previous studies have shown no association between the MTHFR C677T polymorphism and T2DM among Taiwanese, Tunisian, Brazilian, German and Czech populations. In contrast, other data have indicated a significant association with T2DM among Moroccan, Chinese and Polish populations [25].

\section{Conclusion}

This study is the first to report frequency of C677T MTHFR polymorphism in healthy Bosnian population. We did not find statistically significant difference in frequency of C677T MTHFR polymorphism among males and females subject in representing Southern east Bosnian population. Frequency of the T allele and C677T MTHFR genotype observed in this study is consistent with the data from literature.

\section{References}

1. Yamada K, Chen Z, Rozen R, Maththews RG (2001) Effects of common polymorphisms on the properties of recombinant human methylenetetrahydrofolate reductase. Proc Natl Acad Sci USA 98:1485314858.

2. Goyette P, Pai A, Milos R, Frosst P, Tran P, et al. (1998) Gene structure of human and mouse methylenetetrahydrofolate reductase (MTHFR). Mamm Genome 9: 652-656.

3. Micheal S, Qamar R, Akhtar F, Khan MI, Khan WA, et al. (2009) MTHFR gene C677T and A1298C polymorphisms and homocysteine levels in primary open angle and primary closed angle glaucoma. Mol Vis 15: 2268-2278.

4. Kang SS, Wong PW, Susmano A, Sora J, Norusis M, et al. (1991) Thermolabile methiltetrahydropholat reductase: an inherited risk factor for coronary artery disease. Am J Hum Genet 48: 536-545.

5. Rozen R (1996) Molecular genetics of methylenetetrahydrofolate reductase deficiency. J Inherit Metab Dis 19: 585-594.

6. Frosst P, Blom HJ, Milos R, Goyette P, Sheppard CA, et al. (1995) A candidate genetic risk factor for vascular disease: a common mutation in methylenetetrahydrofolate reductase. Nat Genet 10: 111-113.

7. Weisberg IS, Jacques PF, Selhub J, Bostom AG, Chen Z, et al. (2001) The 1298A-->C polymorphism in methylenetetrahydrofolate reductase (MTHFR): in vitro expression and association with homocysteine. Atherosclerosis 156 409-415.

8. Clarke R, Daly L, Robinson K, Naughten E, Cahalane S, et al. (1991) Hyperhomocysteinemia: an independent risk factor for vascular disease. N Engl J Med 324: 1149-1155.

9. Mills JL, McPartlin JM, Kirke PN, Lee YJ, Conley MR, et al. (1995) Homocysteine metabolism in pregnancies complicated by neural-tube defects. Lancet 345 : 149-151.

10. Pepe G, Camacho VO, Giusti B, Brunelli T, Marcucci R, et al. (1998) Heterogeneity in World Distribution of theThermolabile C677T Mutation in 5,10-Methylenetetrahydrofolate reductase Am J Hum Genet 63: 917-920.
11. Guéant-Rodriguez RM, Guéant JL, Debard R, Thirion S, Hong LX, et al. (2006) Prevalence of methylenetetrahydrofolate reductase $677 T$ and $1298 \mathrm{C}$ alleles and folate status: a comparative study in Mexican, West African, and European populations. Am J Clin Nutr 83: 701-707.

12. Sadewa AH, Sunarti, Sutomo R, Hayashi C, Lee MJ, et al. (2002) The C677T Mutation in the Methylenetetrahydrofolate Reductase Gene among the Indonesian Javanese Population. Kobe J Med Sci 48: 137-144.

13. Alfirevic Z, Simundic A-M, Nikolac N, Sobocan N, Alfirevic I, et al. (2010) Frequency of factor II G20210A, factor V Leiden, MTHFR C677T and PAI-1 $5 \mathrm{G} / 4 \mathrm{G}$ polymorphism in patients with venous thromboembolism: Croatian case control study. Biochemia Medica 20: 229-235.

14. Rosenberg N, Murata M, Ikeda Y, Opare-Sem O, Zivelin A, et al. (2002) The frequent 5,10 -methylenetetrahydrofolate reductase C677T polymorphism is associated with a common haplotype in whites, Japanese, and Africans.. Am J Hum Genet 70: 758-762.

15. Botto LD, Yang Q (2000) 5,10-Methylenetetrahydrofolate reductase gene variants and congenital anomalies: a HuGE review. Am J Epidemiol 151: 862 877

16. Födinger M, Hörl WH, Sunder-Plassmann G (2000) Molecular biology of 5,10-methylenetetrahydrofolate reductase.. J Nephrol 13: 20-33.

17. Ueland PM, Hustad S, Schneede J, Refsum H, Vollset SE (2001) Biological and clinical implications of the MTHFR C677T polymorphism. Trends Pharmacol Sci 22: 195-201

18. Žuntar I, Topić E, Antoljak N (2003) Polimorfizam C677T MTHFR gena, homocistein, folati i vitamin B u ateroskleorozi. Biochemia medica. 13:3-13.

19. Adams M, Smith PD, Martin D, Thompson JR, Lodwick D, Samani NJ (1996) Genetic analysis of thermolabile methylenetetrahydrofolate reductase as a risk factor for myocardial infarction. QJM 89: 437-444.

20. Christensen B, Frosst P, Lussier-Cacan S, Selhub J, Goyette P, et al. (1997) Correlation of a common mutation in the methylenetetrahydrofolate reductase gene with plasma homocysteine in patients with premature coronary artery disease. Arterioscler Thromb Vasc Biol 17: 569-573.

21. van der Put NM, Eskes TK, Blom HJ (1997) Is the common 677C-->T mutation in the methylenetetrahydrofolate reductase gene a risk factor for neural tube defects? A meta-analysis. QJM 90: 111-115.

22. Wald DS, Wald NJ, Morris JK, Law M (2006) Folic acid, homocysteine, and cardiovascular disease: judging causality in the face of inconclusive tria evidence. BMJ 333:1114-1117.

23. Couturaud F, Oger E, Abalain JH, Chenu E, Guiasa B, et al. (2000) Methylenetetrahydrofolate Reductase C677T Genotype and Venous Thromboembolic Disease. Respiration 67: 657-661.

24. Ou CY, Stevenson RE, Brown VK, Schwartz CE, Allen WP, et al. (1996) 5,10 Methylenetetrahydrofolate reductase genetic polymorphism as a risk factor for neural tube defects. Am J Med Genet 63: 610-614.

25. Al-Harbi EM, Farid EM, Gumaa KA, Darwish AH, Alenizi M, et al. (2013) Genetic combination of angiotensin-converting enzyme with methylene tetrahydrofolate reductase polymorphisms and the risk of type 2 diabetes mellitus in Bahrain. $J$ Renin-Angiotensin Aldosterone Syst. 